\title{
Tadeusz Lewaszkiewicz, Język powojennych przesiedleńców z. Nowogródka i okolicy, Wydawnictwo Naukowe UAM, Poznań 2017, ss. 512
}

Autor, wybitny slawista, a z pochodzenia prawie nowogródczanin (urodzony w Słońsku, ale w rodzinie przesiedleńców z Nowogródczyzny), tak formułuje przedmiot i cel swojej pracy: „Przedmiotem pracy są wybrane zagadnienia fonetyki, fleksji i składni języka powojennych przesiedleńców z okolic Nowogródka, ich dzieci urodzonych już na ziemiach zachodnich, znajomych moich rodziców oraz dwóch osób, które pozostały po wojnie w Nowogródku. Do przesiedleńców zaliczyłem również niewielką grupę emigrantów - kilka osób z rodziny nowogródzkiej w USA i Wielkiej Brytanii. [...]

Większość moich informatorów pochodzi z Grabnik, wsi znajdującej się przed drugą wojną światową dwa kilometry od Nowogródka. W latach 60. Grabniki zostały włączone do zespołu miejskiego. Niektórzy przesiedleńcy urodzili się w Nowogródku, inni we wsiach pod Nowogródkiem - w Milkiewiczach i w Bajkach.

Cel pracy jest kompleksowy. Na podstawie zebranego materiału wydobędę z poszczególnych idiolektów wybrane elementy z fonetyki, morfologii i składni nowogródzkiego języka kresowego. Są to archaizmy peryferyjne, interferencyjne elementy pochodzenia białoruskiego, rosyjskiego i rzadko litewskiego, różnego typu innowacje północnokresowe. Dzięki wykorzystaniu tekstów rękopiśmiennych (zeszytów szkolnych, listów, notatek itd.) z wcześniejszych okresów życia informatorów możliwe będzie przynajmniej częściowo odtworzenie ich dawnego języka potocznego. Następnym celem jest ukazanie podobieństw i różnic między poszczególnymi idiolektami oraz udokumentowanie procesu wyzbywania się cech języka kresowego pod wpływem języka ogólnopolskiego, czyli przedstawienie rezultatów integracji językowej przesiedleńców z językiem ogólnopolskim. Odnotuję również ważniejsze przejawy 
oddziaływania języka dawnych mieszkańców okolicy Nowogródka na język ich dzieci urodzonych na ziemiach zachodnich" (s. 11-12).

Wprawdzie autor się zastrzega: „Jako że praca dotyczy głównie języka mojej rodziny i powinowatych, odwołuję się do wydarzeń z jej dziejów oraz anegdot rodzinnych, dokładnie też opisuję kompetencję językową - własną i moich informatorów. Mogę spotkać się z zarzutem, że do rozważań naukowych wprowadzałem zbyt często «osobistą narrację», zwłaszcza dotyczącą refleksji o własnym rozwoju językowym" (s. 12), jednak takie zarzuty są nieuzasadnione. Trzeba się z badaczem w pełni zgodzić. Wystarczy tu przypomnieć dobrze znany językoznawcom fakt, że najlepsze opisy gwar wyszły spod pióra autochtonów - by się ograniczyć do kilku tylko nazwisk wybitnych dialektologów, takich jak Władysław Brzeziński, Mieczysław Karaś, Józef Kąś, Marian Kucała, Honorata Skoczylas-Stawska, Augustyn i Wiktor Steffenowie, Bernard Sychta, Mieczysław Szymczak. Na ten element „bliskiej relacji z respondentami" kładzie też nacisk recenzent wydawniczy książki - prof. Maria Peisert z Uniwersytetu Wrocławskiego. Trudno sobie wyobrazić korzystniejszą dla nauki sytuację od tej, gdy z doskonałą znajomością (z autopsji) danej odmiany językowej idą w parze rozległe kompetencje językoznawcze. A w wypadku Tadeusza Lewaszkiewicza są to kompetencje naprawdę imponujące - nie tylko dialektologiczne, lecz także historycznojęzykowe i slawistyczne (np. kto z dialektologów wie - a Lewaszkiewicz wie! - że w Leksykonie Jana Mączyńskiego, pochodzącego z ziemi sieradzkiej, są zapisy dowodzące wymowy typu ojcieć, więćldac, tokiec?).

Ze swej strony podkreśliłbym tutaj kilka spraw.

A. Zwracają uwagę rzadko wyzyskiwane w badaniach dialektologicznych (w najszerszym tego słowa znaczeniu) świadectwa rękopiśmienne, takie jak zeszyty szkolne, listy, kartki pocztowe, wspomnienia rodzinne, brudnopisy podań urzędowych, notatki służbowe, luźne notatki prywatne. Autor uważa je - i słusznie - za ważne źródło materiału językowego o charakterze historycznym i (niezależnie od Aneksu (s. 475-509), który, złożony z dwu części rękopisów i zdjęć, wydatnie podnosi wartość dokumentacyjną książki) dość często ilustruje swoje wywody podobiznami fragmentów tego rodzaju źródeł rękopiśmiennych.

B. Należy usilnie podkreślić samoistną wartość informacyjną (do wyzyskania w dydaktyce na szczeblu magisterskim i doktoranckim) paragrafu poświęconego podstawom teoretyczno-metodologicznym pracy oraz zastosowanemu przez autora instrumentarium badawczemu (za szczególnie wartościowe uznałbym nacjonalne - a jednocześnie przystępnie sformułowane, widać, że głęboko „przetrawione” i będące owocem własnych przemyśleń i doświadczeń badaw- 
czych, a nie tylko biernej lektury - uwagi o strukturalizmie, o teorii kontaktów językowych i o wspólnotach komunikatywnych).

C. Równie usilnie trzeba podkreślić samoistną wartość informacyjną paragrafów dotyczących stanu badań nad genezą polszczyzny kresowej i polszczyzny przeniesionej z Kresów północno-wschodnich. Niby sprawa jest znana. Po lekturze ujęcia Tadeusza Lewaszkiewicza zyskujemy jednak jej całkiem nowy obraz - a to za sprawą rzadkiej w tym stopniu umiejętności jasnego i przejrzystego problematyzowania najbardziej nawet skomplikowanych zagadnień. Autor jest tą umiejętnością obdarzony w wyjątkowo wysokim stopniu. Zwłaszcza zyskuje w autorskim przedstawieniu Lewaszkiewicza problem genezy polszczyzny Kresów północno-wschodnich, głównie genezy polskich wysp językowych na Wileńszczyźnie. Przeciwstawne stanowiska (z jednej strony Kazimierza Nitscha i Haliny Turskiej, z drugiej zaś - Tadeusza Lehra-Spławińskiego, Józefa Trypućki i Ireny Maryniakowej) zostały wyartykułowane już dość dawno i od tego czasu brakowało wypowiedzi na ten temat wybitniejszych uczonych. Stąd ważna rola wypowiedzi Lewaszkiewicza, choć trochę szkoda, że została ona sformułowana ze stosunkowo rzadko spotykaną u tego wybitnego badacza ostrożnością: „Moje stanowisko jest w tej sprawie kompromisowe. Pogląd na genezę polszczyzny północnokresowej K. Nitscha i H. Turskiej dotyczy zwartego obszaru kilkudziesięciu wsi i miasteczek na północ od Wilna, od którego był oddzielony kilkunastokilometrowym pasem wsi białoruskojęzycznych. W samym Wilnie mieszkało sporo Polaków, ale nie stanowili oni większości. Do pierwszej wojny światowej przeważali mieszkańcy żydowskiego pochodzenia (posługujący się głównie językiem rosyjskim, tzw. litwacy), sporo było Rosjan, Białorusinów i Polaków, zaledwie kilka procent Litwinów. Procentowy udział polskiej ludności w Wilnie wzrósł po pierwszej wojnie światowej. Mniejsze polskie skupiska językowe istniały w rejonie Kowna i Smołw.

Wydaje mi się nieprawdopodobne, aby przed XIX w. na późniejszym polskojęzycznym obszarze na Wileńszczyźnie Polacy stanowili bardzo mały odsetek ludności. Sądzę, że istniały tam już przed rozbiorami mniejsze i większe wyspy polskojęzyczne, które oddziaływały na litewskich mieszkańców, powodując w ciągu XIX w. ich szybką polonizację. W latach 20. i 30. XIX w. wśród najstarszych mieszkańców sporą grupę stanowili tam jeszcze ludzie dwujęzyczni (znający polski i w różnym stopniu litewski), ale nie było już mieszkańców jednojęzycznych, tj. posługujących się wyłącznie litewskim.

Nie można ignorować wyników badań $\mathrm{H}$. Turskiej, która metodą wywiadów zebrała istotne informacje dotyczące sytuacji językowej nawet w połowie XIX w. Badania te nie upoważniały jednak do wyciągnięcia wniosku, że przed 
XIX w. nie istniały na tym terenie wyspowe skupiska użytkowników polskich gwar północnokresowych. Jeszcze bardziej może dziwić stanowisko K. Nitscha, który przyjął często hipotetyczne założenie, że przed XIX w. nie było w zasadzie na Wileńszczyźnie polskojęzycznej ludności wiejskiej” (s. 30-31).

D. Na koniec należy przypomnieć, że Tadeusz Lewaszkiewicz, który $\mathrm{W}$ omawianej tutaj pracy przedstawił wybrane zagadnienia fonetyki, fleksji i składni polszczyzny nowogródzkiej (inne kwestie pozostawiając do odrębnych artykułów), zapowiedział osobną pracę (chyba książkę) poświęconą leksyce (wraz z frazeologią i frazematyką) tej polszczyzny (,,[...] dokładniej opracuję słownictwo przesiedleńców z Nowogródka i ich dzieci w osobnej publikacji, która obejmie słownik i analizę zebranej leksyki”, s. 391). Tutaj pomieścił tylko słownik (właściwie indeks) 4200 leksemów (liczba wcale znaczna) - typowych kresowizmów polskiego pochodzenia oraz kresowizmów frekwencyjnych, białorutenizmów, rusycyzmów, archaizmów, formacji potencjalnych, neologizmów, ekspresywizmów itd., opatrując hasło jedynie definicją znaczeniową (zwykle synonimiczną). Sam autor pisze: „W niniejszej monografii zamieściłem jedynie uproszczoną wersję słownika, w którym znajdują się nie tylko typowe wyrazy kresowe. W przyszłości opublikuję dokładny słownik języka przesiedleńców z Nowogródka i okolicy" (s. 11). Całemu polskiemu i słowiańskiemu środowisku językoznawczemu nie pozostaje nic innego jak uzbroić się w cierpliwość i czekać.

W konkluzji należy stwierdzić, że powstała książka wybitna, która znajdzie poczesne miejsce nie tylko pośród opracowań traktujących o polszczyźnie północnokresowej. 

